\title{
Research informed gardening activism: steering the public food and land agenda
}

\author{
Chiara Tornaghi \& Barbara Van Dyck
}

This is a final draft of Tornaghi, Chiara, and Barbara Van Dyck. "Research-informed gardening activism: steering the public food and land agenda." Local Environment ahead-ofprint (2014): 1-18.

For referencing please check at http://dx.doi.org/10.1080/13549839.2014.949643

\begin{abstract}
Drawing on the authors' personal experience in the Edible Public Space project (Leeds, UK), this paper explores the spheres of influence and contradictions that shaped the project trajectory. We identify and analyse the dynamics and contradictions at play in the formation of an urban gardening group grown out of a coming together of scholarly and committed action ambitions and aim to capture learning elements for scholarly activism, political gardening and radical urbanism.

We explore the action research intervention through a framework of social transformation in and through spatial interventions. We frame our discussion in a threefold conceptual framework: (i) a discussion on shifting planning arenas and their understanding in social innovation; (ii) an overview of the role of political gardening practices, an in particular food commons - food sovereignty initiatives in envisioning and implementing alternative urbanism; and (iii) a discussion on reflexivity and learning, through a thick case study description in which we also unpack our own engagement and positionality. Doing so, we aim to contribute to the creation of an active memory of political gardening. The paper will speak in particular to a rising number of researcher-gardeners-environmentalists, and aims to problematise the links between politically-research-informed strategic thinking and actions, and the vocation of critical urban theory to provide and make visible alternatives for social change.
\end{abstract}

Key words: political gardening; alternative urbanism; activism; public space; food; actionresearch

\section{Introduction}

In the city of Leeds, West Yorkshire UK, ongoing and recent collective gardening experiences provide groups of people with the necessary ingredients allowing them to discover the taste to work together on imagining and building better futures. In many cities in the global North, urban food growing initiatives indeed shape spaces that bring together people from a vast array of backgrounds and seem to offer an antidote for the risk of 
paralysis at moment when further enclosure and expropriation in all spheres of life are presented to us as the only possible way forward.

Such liberating experiences confront us with questions of how to capture and unravel these 'events' to build the knowledge that can push us beyond the known and into experiment. David Vercauteren (2011) points to the need of creating memories of experience. Such memories make us aware to be part of a history with a past and a future, and still according to Vercauteren (2011), the feeling of 'being preceded' may give the strength to continue to experiment in ways of doing.

The creation of an active memory (Stengers 2005) of the political gardening movement, or the documenting of precedents of success and failure, we argue here, also builds a community of scholar activists that are both actors, and authors in the storytelling of, these learning experiences. The marriage of being involved as both a scholar and activist in gardening issues raises questions as much on how to critically act in the creation of these spaces, as on how to tell research informed stories from below.

The participation in scholarly meetings on food growing as well as gardeners gatherings brought us in contact with a number of scholars that have opted for a path of both studying gardening practices and be politically active. A choice that entails a continuous process of negotiating the conflicting demands of political engagement and academic performance (Pulido 2008). The way scholars engage with activist work will, as Laura Pulido (2008, p 349) states, directly influence the type of scholarship they engage in. The forms of engagement with scholarly activism, she continues, come from different spheres of influence that relate both to larger political events and personal dynamics. Scholarly activism's aim is to shape the social struggles that scholars engage with. How this has to be done, and its consequences, is subject of continuous debate (e.g. Gibson-Graham 2008, Brenner 2009, Marcuse 2009, Piven 2010).

In this paper we explore the spheres of influence in shaping the trajectory of a gardening project. We identify and analyse the contradictions that are present in the specific formation of an urban gardening group grown out of a coming together of scholarly and committed action ambitions and seek to capture learning elements for scholarly activism, political gardening and radical urbanism. The experience we draw upon, describe and untangle is the story of the creation and running of a small gardening site in Leeds, the 'Buslingthorpe Walk edible public garden'. Both the authors of this paper have been directly involved in this project since the onset as, respectively, member of the coordination team of a research project (Van Dyck) and the co-coordinator of the 'Public Space Public Produce' group that promoted the gardening project (EPS, Tornaghi). We actively problematize our role in the EPS gardening project, respectively as a critical sparring partner and as a research informed activist.

In the remaining of this introduction we will outline a brief storytelling of the project. We will then proceed, in section 2 , by laying out a theoretical and conceptual framework including: (i) a discussion on shifting planning arenas and their understanding in social innovation; (ii) an overview of the role of political gardening practices, an in particular food commons-food sovereignty initiatives is envisioning and implementing alternative urban settings; and (iii) a discussion on reflexivity and learning, through unpacking our own engagement, distance and active memory. In section 3 we unfold the making of political gardening in the EPS project, applying the analytical concepts identified in section 2, before ending with some concluding notes on learning elements from and for the researchergardeners and on the way social change is experimented in practice and research. 


\subsection{Challenging neoliberal urbanism}

The Leeds based political gardening project took its first steps as a stance towards two main conditions of neoliberal urbanism. The first is the shrinking freedom in the use of public space, with its associated raising surveillance, commodification and enclosure, which is particularly pronounced in the British urban realm (Minton 2012, Hodkinson 2012). The second is the almost complete subjugation of civil society to an industrialised food system, which has naturalised the loss of the right to find or to grow food on the earth, in a way that does not require a monetised transaction (Heynen 2010). These two conditions, which are actually very common in many cities of the Global North, seems to be the outcomes of modernism-informed planning practices, amplified and epitomised by the restructuring needs of capitalism, under the most recent neoliberal agenda (Steel 2008, Tornaghi 2014). Within this framework, the authors intended to instigate a process of learning through doing, which would have not only created a tangible evidence for an alternative design and use of public space (as building block for an alternative urbanism), to trigger planners and public land managers imagination, but which would also enable the exchange of skills among project participants and the consolidation of a group able to handle the various aspects of a 'food-including' urban realm. In short, the project idea was born out of an activist desire to challenge the shrinking freedom in the use of public space and the subjugation of all "eaters" to an industrialised food system.

A mini-grant from an action research project shaped its form and pushed for further reflection. During 2010-2011 several action researchers in the UK and Belgium received a small grant from a transdisciplinary research project ${ }^{[1]}$. The SPINDUS project experiments with the status of practice and theory as a locus for critical action in the fields of spatial planning and urban design. To that purpose it provided small grants aimed at documenting actions seeking to identify and enhance user oriented spatial quality, and to report back on it. In Leeds it turned out to provide the little push needed to bring together social researchers and long-term environmental campaigners.

\subsection{From tipping corner to 'stealable' food provision: the place, the story}

Leeds is a city of approximately 800 thousand inhabitants. The food growing community, despite not being as wide and active as the London one, is quite variegated. Leeds is home of the British Permaculture Association, and of one of the key hubs of Groundwork and TCV (formerly BTCV), the two largest environmental charities in UK engaged with environmental protection and education.

After having discussed the idea of Edible Public Space (EPS) rather informally within a core group of 3-4 people (we will come back to the genesis of the project later on in this paper) and incorporated the inputs of the funders, the EPS project was open to the public in September 2010, with the organisation of a public meeting in a community room in Leeds city centre. The event, widely advertised in a range of circles, was participated by a variegated group of about 25 individuals variously interested in food growing, public space and the environment: artists-activists and public space reclaimers, social workers involved in educational food growing, landscape designers, transition towns activists, landsharers, community forest gardeners, permaculture designers, urban foragers and the likes. The first 
meeting was an opportunity to discuss visions and qualities of an edible public space, and discuss initial steps to move from concepts to practice. The meetings continued two to three weeks apart for a few months, and included urban explorations, bicycle excursions, site evaluations, visioning and planning meetings, convivial and playful community events, and negotiations with local government officers until when, in April 2011, EPS has been finally granted permission to create the "Buslingthorpe Walk edible public garden" in Chapeltown, a neighbourhood in the north of Leeds.

The site selection came out of a series of meetings in which the participants identified places to visit, guide the group on site for an exploration, did research further the history of the site, and undertook a post-visit collective evaluation. Criteria for the evaluation were organised in a matrix which included, among others, soil quality and aspect, expected benefits for the neighbouring communities and the possibilities of connecting to a wider ecological system. Location in the neighbourhood, group members' engagement in the neighbourhood context and life, existence of local claims for land and growing spaces.

While discussions among the members of the rather fluid group, and the negotiation of the land with the council took almost eight months, the creation of the garden was relatively quick. The garden is located in the corner of a narrow and long grassed strip of land known as Buslingthorpe Walk, a place with a long history of neglect, fly tipping and drug smuggling. The community garden is very different from the most common individually allocated allotments or the enclosed/gated community gardens run by other organisations: located on public land, openly accessible and collectively looked after, the key principle is the non-ownership (or rather the collective ownership) of seeds, plants and produce. Everyone can plant and everyone can harvest. The driving need of the project has not been achieving produce in the short term, but rather contributing to food and land justice in the long term.

\section{Creating the conditions for insurgent planning arenas to emerge}

\subsection{Transcending plan-build-use logics}

Frequent reference to concepts as scholar activism (Castree 2002, Routledge 2004, Gibson-Graham 2008), action research (Pain 2003, Cahill 2007), transdisciplinarity (Moulaert et al. 2013, Madanipour 2013) in spatial disciplines, including geography, spatial planning and urban design, all reflect the search for ways of knowledge production that does not start from the idea of a safe distance between the researchers and critical action. The aforementioned works have in common to start from the importance of critical action through researchers engagements with spatial practice. However, how to do so, remains much debated (Gibson-Graham 2008, Piven 2010). Reversely, practice-based research and other models of transdisciplinary research are today acknowledged as valuable models for knowledge building on space (Doucet and Janssens 2011, Madanipour 2013, Moulaert et al. 2013).

The perspective on political urban gardening developed in this paper starts from thinking space not as something finished but as possibly emerging from and through social interaction (Massey 2005). It adopts a relational ontology for thinking space that includes physical and social phenomena and the relationships with one another (Lefebvre 1991). It 
brings together analytical approaches from the social sciences (in casus sociology and human geography) with the projective and action-oriented approach of urban planning and design. In articulating the built environment, the environmental and the social, the approach also builds on the social innovation literature that engages with questions of socio-spatial transformation, including the transformation of institutions, overthrowing oppressive 'structures with power', facilitating collective agency to address non-satisfied needs, building of empowering social relations (Moulaert et al. 2013).

The coming together of a diverse range of people - researchers, growers, environmental activists, policy makers - around what Latour (2004) coined a "matter of concern" (here the possibility of producing edible public space) and its role in fostering the conditions for what could be seen as the emergence of an insurgent planning arena is therefore a crucial question when looking back at the EPS project.

The interest in "shifting planning arenas" stems from the observation that urban development processes typically involves a separation between those who plan, those who build and those who use these very spaces. As a result, plans and projects do not necessarily reflect needs, dreams and desires of diverse urban communities. Occasionally, however, the boundaries of the design/plan-build-use logic are transcended. We argue that the rise of political gardening initiatives points to potentialities of levering the capacity of a priori informal actors to transcend boundaries in defining and negotiating spatial agendas (Le Strat 2004). Political gardening has produced promising spaces to weave in desires, introduce new temporalities and rethink the relationship between people and their environments into urban planning proposals (see e.g. Petcou and Petrescu 2008). Political gardening initiatives indeed have been identified as tactics for addressing multi-scalar issues and questioning salient consensuses and working towards wider [political] goals in different urban domains (racism, food growing, community building, access to land, ...). They include discrete but tangible actions on a constraint space. This, according to Petcou and Petrescu (2008) allows people to appropriate spaces and from there on move forward towards addressing broader societal issues in ways that are less dependent on wider political alliances, policy agendas or economic ventures.

Critical notes on the emancipatory power of such small initiatives is necessary (Andres 2012). Claire Colomb (2012, p 147) for example notes that, and despite scholars and activists hope and intentions of fostering empowerment, work in/on the margins tends not to go beyond appeasing the established status quo or even "becomes instrumental in paving the way for profit-oriented urban redevelopment processes and displacement". Thick descriptions of what is actually going on in the margins have shown that, occasionally, the transformative power however does emerge from cracks or interstices (Lévesque 2002, Jamar 2012, Mariani and Barron 2014).

\subsection{Political gardening as insurgent planning arena}

In the last 5-10 years, urban gardening and urban farming have become very popular activities across cities of the Global North. Grassroots-initiated community gardens have been mushrooming around neighbourhoods, from vacant plots in Detroit to rooftops in London, New York and Chicago, adding to the already existing range of collective gardens hidden behind the walls of health, education and social care institutions (i.e. schools yards vegetables gardens, healing and therapeutic gardens within hospitals, mental health services hubs, etc.). While agriculture is not a novelty for western cities (Steel 2009), the 
discontinuity of this practice since the end of WWII (or sometimes longer) has been deep enough for a society to have almost completely lost memory of its ordinarity in daily life, and to be celebrated today as an extraordinary novelty. The current resurgence of food growing is generally celebrated as a rediscovery of the community (Hou et al 2005, Holland 2004, Glover et al 2005, Firth et al 2011), a sign of a reconnection with food (Garnett 1996, Howe and Wheeler 1999) and a manifestation of healthier life-stiles (Armstrong 2000, Milligan et al 2004, Wakefield et al 2007, van den Berg 2010).

While this proliferating landscape of gardening practices is all but free of traps, such as new forms of gentrification and displacement (Dooling 2009), garden-led speculative redevelopment or opportunities for corporate green wash (Jackson 2009), much of the recent interest for urban gardening is perhaps due to the claims associated to these practices, and in particular the potential of political gardening for enacting a "politics of possibility" (GibsonGraham 2006), challenging the neoliberal logic that rules urban life and shapes the urban form, enabling alternatives to emerge.

By rearticulating the relationship between local communities, food and land use, these initiatives are enacting forms of food sovereignty at different scales, thus undermining a pillar of neoliberal capitalism. So, while a number of scholars are pointing our attention to the need to critically assess these practices (Pudup 2008, Saed 2013, McClintock 2013, Tornaghi 2014), political gardening is increasingly analysed as an insurgent practice.

We can identify at least three main strands within this literature, where food growing and urban gardening and farming are conceptualised as a political act impacting on the ecology of space.

The first look at the individual sphere, where individual forms of back (or front) gardening and animal breeding are understood as forms of self-provisioning (Irvine 1999) claims of independence from the agro-business and supermarket-driven diet and contestations to the dominant meaning and shape of urban space. Food growing in the private home garden can be seen as an individual act, contesting and reverting the (class dominated) aesthetic of the lawn (Robins and Sharp 2003) and land politics, with their planning-enforced division between dwelling and farming (Bartling 2012), an act of production of a home ecology that claims a right to the city as a right to contribute to urban metabolism (Shillington 2013) or, as Tom Hodgkinson put it, a food provisioning selfliberating practice, where "digging is anarchy, anarchy in action" (Hodgkinson 2005).

The second strand look at solidarity economy, alterity and a new placeembeddedness of food (Harris 2009, Marsden and Franklin 2013). Rooftop farms, peri-urban smallholding, new market gardens, are increasingly often networked into alternative food networks, also called "food hubs", which link growers, distributors and consumers. These are new articulations of the relationship between community and place that takes shape by reworking the economic relations, socio-environmental ethics and place-embeddedness related to food. Food hubs aim to create and empower short supply food chains, supporting market demand for small local food producers, by re-embedding food production and consumption into the local geography of place, and by deliberately contributing to food justice in the form of fair pay for food growing workers, and a more responsible use of environmental resources.

The third strand look at urban food growing as a form of rebuilding the Commons. A number of food growing projects, part of the pan-european Reclaim the Fields constellation (for example the British 'Grow Heathrow') as well as a number of LandShare projects (see for example the Canterbury's Transition City Allotment in Pinkerton and Hopkins 2009) and grassroots community gardens, are set up with the explicit intent of 
sharing ecological resources, creating food commons, and in so doing contributing to food sovereignty.

All these three categories represent examples of insurgent urbanism, forms of reappropriation of the right to shape people's own living environment both through direct acts on the materiality of space as well described by Jeffrey Hou (2010) in his edited collection, and through radical planning practices, what Miraftab describe as 'counterhegemonic, transgressive and imaginative practices' that respond to neoliberal specifics of dominance through the principle of inclusive governance (Miraftab 2009).

Edible Public Space, with the intent of challenging the institutional prerogative of defining, designing and regulating public spaces, by creating a 'public abundance' and making food openly accessible, would fall into the third broad family of political gardening sketched above.

\subsection{Reflexivity and learning}

As critical scholars, our participation, and indeed a key role in a case of political gardening has not come without concerns and over alerted self-awareness. We have been in constant tension (Pulido 2008) between our role of activists, that experiment with transformative practices and face the risks of their cooptation (Colomb 2012), and our role of researchers, vigilant but also engaged with the challenge of providing tools for alternatives practices (Brenner 2009, Marcuse 2009). Is this tension a contradiction? This paper aims to problematise the links between politically-research-informed strategic thinking and actions, and the vocation of critical urban theory to provide and make visible alternatives for social change (Marcuse 2009, Brenner 2009). And to accomplish this task we unpack the contradictions and tensions between critical analysis and activist-research, based on thick case description with particular regards to issue of distance and engagement. This exercise is an attempt to contribute to collective effort of mapping experiences of critical action and scholarly involvement with all its contradictions or memory building, and does not have any intention of coming up with guidelines.

Our trajectory of reflexivity and learning will be built on three main blocks of reflections. The first relates most explicitly to how we aim to contribute to building a memory of the gardening movement and is inspired from the conviction and the desire of shaping "performative practices for 'other worlds' "(Gibson-Graham 2008, p 613). Isabelle Stengers (2005, p 998 and cited in Doucet 2011) proposes the concept of the creation of an active memory to document experiences that were promising and turned out to be "failures, deformations or perversions", or on the contrary that made a difference (Vercauteren 2011). Building an active memory by revisiting decisions and experiences is a way to show what works and what doesn't with the ambition to allow the enactment of our concerns and possible futures. Edible Public Space's ambition of envisioning and implementing a radical urbanism is one worth documenting. By making visible the choices that have been made, they can also be repeated or altered in a next experiment that seeks to develop urbanism, based on a gardening initiative based on non-ownership of seeds, plants and produce, reflecting on urban food and land justice in the long term, or playful public space. Sharing the openness to the possibility rather than limits on the possible (Gibson-Graham 2008).

The second building block is the commitment. A critical element of scholar activism is commitment in the sense of being there (in the movement) when needed. Commitment is what can give rise to tension between scholarship and activism, when scholars not just develop critiques but try to advance the ideas and interests of dissident, marginalised or 
voiceless groups (Piven 2010). Commitment probably starts with making political alignments or worldviews explicit. Commitment is also about finding a role in the movement (Pulido 2011), and bringing in skills which can range from making coffee over networking to analysis. This requires a close attention to needs and standpoints of groups. Researchers thus, become actors amidst a number of others around particular issues or questions. Gardeners in turn are not considered subjects of research but knowledgeable participants in the research project. Our interest in the analysis of commitment relates to what Ruth Gilmore (1993, p. 71) referred to as "organic praxis", and which was extended by Laura Pulido (2008, p 342) as "talk-plus-walk" approach or the "organization and promotion of ideas and bargaining in the political arena". This type of commitment also includes writing about the experience both for and beyond academic audiences as well as forms of connection with the movement or practice based on reciprocity.

The last block of reflections about the work of scholar activists is about distance. Distance, or rather the lack of distance is, what gives rise to probably the most widespread critique on pursuing scholarly work at the service of social struggles. Namely the risk to develop overly positive arguments and politically instrumental conclusions at the expense of the ability to keep the required social complexity (eg. Hale 2008). It raises questions on how to balance critical distance with embeddedness, immersion or compliance with the struggle researchers are involved in. The work of Gibson-Graham (2008) on community economies is inspiring in that respect. Referring to an increased consciousness and recognition of scholar activists about the performativity of their knowledge, Gibson-Graham (2008, p 614) argue that it also brings an additional responsibility to scholars "to recognize their constitutive role" in the worlds that exist or might become.

Starting from these insights, we embrace a performative approach to return to EPS and analyse the EPS knowledge production process as part of critical action. This implies not necessarily only to question how our work as researchers contributes to opening up of possibilities, but also to be attentive to how the coming together of people with different backgrounds around the issue of edible public space allows to see things differently.

\section{$3 \quad$ Performing political gardening}

To capture the crucial elements that explain the emergence of EPS as a learning platform, we first identify a number of the initiatives, events and projects that may be seen as EPS predecessors or inspirers and which make up its historical and spatial context. We then unpack the micro-composition of the EPS-group, to come to the ways in which EPS impacted ways of seeing and ways of doing.

\subsection{The birth of Edible Public Space}

The transdisciplinary research project SPINDUS, with a strong focus on methodology as well as the authors' research background, have played a role in the provision of an initial framework for EPS. A relational approach to space, built on insights from different spatial disciplines (see section 2.1), resonated with the authors' questions about (I) the shrinking freedom in the use of public space, (II) neoliberal urban development and social justice, as well as (III) the way these are contested. Issues which all have been fundamental concerns underlying the birth of EPS. These insights combined with a research 
and practice based understanding of the ideas, projects, discourses and actors which act as models to gardeners that fight what Heynen (2010) refers to as (IV) the complete subjugation of civil society to an industrialised food system, provided a solid base on which to build EPS.

The idea of connecting issues of public space, access to food and urban development was initially presented to, and refined together with, people with knowledge in horticulture and conservation (TCV), media and landscape design and permaculture before opening up to a range of gardeners and people active in the Transition City Leeds scene in September 2010.

Tornaghi, the Leeds based researcher-activist-gardener, was at that time exposed to and engaged in a range of loosely connected projects that were symptoms of a changing 'territorial' sensitivity. Back To Front was important in that respect. The NHS funded pilot project in the deprived neighbourhood of Harehills, aimed to promote ethnic and black minorities social engagement and health, through the encouragement of front gardening. Partnering with students in landscape design at Leeds Metropolitan University and with TCV the project explored community interest in the initiative, and piloted the design and implementation of a few front gardens. One key aim of the project was to challenge the aesthetic of the grassed or concreted-over front gardens, and normalise the existence and view of vegetables and their beauty. While Back to Front was looking into what gardening small private spaces can bring as a snowball effect on the community, other groups were exploring issues of engagement and public space more directly.

Tinwolf, a subgroup of Transition City Leeds, was experimenting with initiatives of sharing land (LandShare) and therefore exploring forms of reconnecting the community, sharing resources and fostering re-skilling. However, the initiative was not very successful in its aims. The transient student populations in Leeds (leaving the house in the middle of the growing season) or the very enclosed form of houses and gardens (making it difficult to access gardens unless owners are at home, and willing to engage with the guests) did not help to ensure the success of the project and its continuity.

Make-Pla(y)ce is another defining project in EPS genesis. Make-Pla(y)ce more directly interested in reinterpreting and transforming the sense of place -and in particular of public space- , through playful sessions, improvised play with whoever would turn up at the fortnightly meetings, and an intentional rediscovery of all the human senses to feel the city. Food and nature were two among the themes explored in these sessions. Elegant dinner parties with crystal glasses and candles were improvised in interstitial neglected places in the city centre, offering opportunities of insurgent conviviality. Similarly, countryside-inspired picnics were improvised in front of the city Art Gallery, where food rescued from skips was shared and eaten among the participants. Make Pla(y)ce was a great way to open up to the new, engage with strangers and play with the city, but the temporality of its sessions prevented from marking more permanently and more visibly the fabric of the city. While these ephemeral events were great inspires, the projects helped to mature, in some of its participants, the desire to experiment with more tangible and long lasting interventions in the public space of the city.

In that period, members of the Leeds permaculture network developed interesting ideas and practices. One allotment in a peripheral area of the city for example, was cultivated with permaculture principles, and opened once a month for learning. Although the allotment was for most of the time gated, and the produce was never explicitly in shared ownership, 
the site acquired very similar features of a public space during that open moments. Other members of the same network engaged in the locally run Permaculture Design Diploma and produced plans for permaculture landscaped edible gardens of various greens and pieces of land scattered around the city, as part of their training for the Diploma, but with no obvious intention to make these plans become reality. The only exception to this was the plan for a forest garden in a woody and secluded piece of land that started at the same time as EPS. One member of the permaculture network was even occasionally providing professional services to support the creation of edible gardens in community centres or for third sector organisations, without however bringing this at large.

Tornaghi, who at that time was involved in almost all of the above initiatives and in a break between academic contracts, brought together some of the people engaged in these projects and started imagining what may become possible when they would join forces and how such cooperation could actually work. The first person she approached was engaged in Back to Front. Professionally, he would have had the skills and the tools to lead the creation of a garden. Around the same moment, it happened that he was putting together a funding bid for the creation of what he called 'Garden to Eat', a project looking for building on the knowledge collected through the survey for Back to front, but more generally open to other forms of gardening. EPS was probably nowhere near the scale of what he had in mind, but the idea of starting something concretely, on the ground, resulted appealing, and lead to the discussion of possible design, locations, materials, forms of engagement with the community, as well as on possible future outcomes.

Following this encounter a musician and video maker, who just finished his master studies in landscape design was contacted. At the time he was authoring a film that explored how a contemporary medium sized city like Leeds could have become a living reactualisation of a garden city and from what historical and more actual ideas and theories this could emerge. He also clearly had a vision for a large scale change. His attempt to build this vision was enacted virtually, as a collage of interviews, rather than through a 'hands on' approach. He joined in with a bunch of music instruments and a videocamera to document and tell the story of what we were making happen.

The fourth person that got involved was a member of the permaculture network and a professional horticultural service provider. This permaculture designer at the time was developing a local nursery with selected plants. This core group called for a first Edible Public Space meeting. Transitioners, forest gardeners, the academics involved with Back to Front, artists engaged in public space and public art, food and gardening educators working with various disadvantaged people, from street drinkers to asylum seekers, and a number of other members of the community joined in.

\subsection{Edible Public Space as "unexpected on the ground": a tool to acquiring ways of seeing}

From the early meetings, it soon became clear to the EPS participants that, despite the variety of existing food growing projects in Leeds, at least two issues were not at the core of any of these other projects. The first one was "public space": there was not a food 
growing project that was mainly set in a public -and publicly accessible- space. Edible Public Space wasn't just a community garden, EPS was claiming the right to the city as a right to food, right to forage, right to shape urban space and right to use it in a convivial, non-commoditised way, while doing gardening.

The second one was the lack of a city wide urban agricultural project, which aimed at increasing production and distribution of local food. Many of the participants, in fact, were more than just passionate gardeners, but rather shared an environmental ethic that recognised the need to shorted food supply chains and coordinate a more sustainable and localised food system. While EPS was not clearly aiming to substantially produce and distribute food, discussion around EPS let emerge this point, and the awareness that this goal could only have been achieved through a wide involvement of local groups and the development of a large community organisation with entrepreneurial capacities. With this in mind the EPS project defined itself as a learning ground.

The first meetings revealed the ideas that were feeding the imaginaries of these people. CPULs, or Continuosly Productive Urban Landscapes, for example, was a model for ecological intensification via urban agriculture, developed by architects Bohn and Viljoen, both founders of an European group of sustainable food planners. Their homonymous book (Bohn and Viljoen 2005) was becoming fairly known within and beyond academia, and was a reference point at least for the academic component of the group. At the same time, in the small town of Todmorden, a couple of committed growers started to do guerrilla gardening in unusual places, including in front of the police station, and getting quite a lot of media attention. While the conditions of a tiny town with little more than 14,000 inhabitants is hardly comparable to that of a 60 times larger city, the project surely helped to make the idea of claiming ownership of public space less alien. Nonetheless, EPS's strategy differed from guerrilla gardening in its approach to claiming land. While direct action has always been in the realm of possibilities, the main adopted strategy has been to take the 'legal way'. This was due to both the diverse range of groups members - not all keen in contravening rules, or engaged in labour relationships with the council they did not want to put into danger - as well as to previous experiences of guerrilla gardening that periled under likely ignorant grass mowers unaware of the edibles they were abating.

The project was therefore phased following council rules for the organisation of a street event, raising public awareness and community engagement for preparing a successful land negotiation with the council, and hopefully lead towards a long term, sustainable, urban agricultural project.

Reflecting back on this early start of EPS is revealing how much has been possible to condensate, symbolically, into it: claiming and transforming publicly owned land, establishing an edible garden far away from a gated allotment and right in the middle of a busy green pathway, playing food-related treasure- hunts with local kids, betting on the positive reaction of a too often stigmatised neighbourhood.

It is probably the density of its meanings and components that made it easier for participants to have a role, unique and indispensible, and a space where to play it. In retrospective, it is as if this way of working came out so simple that also larger ambitions seemed natural and within reach. When a few months later the core members of the group wearing the different hats of the various projects they have been involved with - found themselves in the boardroom with the Head of Leeds City Council's Parks and Countryside 
sector, they felt empowered to represent the community of local gardeners. Their common experience gave them the symbolic and practical baggage and networks to become more ambitious, and play a different and leading role at city level. Feed Leeds was the newborn. Roles and division of labour in EPS were in large part replicated. At about that time Tornaghi also attracted a much larger research project ${ }^{[2]}$, adding a new layer of dynamics and opportunities for nurturing the learning process of the group.

EPS ideas started to travel quickly since the early inceptions of the project, both in the neighbourhood and elsewhere. At least four different participants started to look into land nearer them to bring it into cultivation with their friends. So, while their involvement has been intermittent, showing that a gardening project itself doesn't necessarily rebuild communities - or at least not in the short term, inspiration permeated through groups boundaries. One of them reclaimed a disused green roof in her housing estate and created a rooftop garden together with her neighbours. Another gardener started to question the ownership of a neglected land adjacent the nursery of her child to transform it in a gardening space with other children's parents. Two more people inquired into our methods, with the intention to develop similar initiatives on council green spaces elsewhere in the neighbourhood. EPS thus helped to see and enhanced the realm of the possible. Spots of neglected land became an object of attention. People had acquired new ways of looking at ordinary spaces surrounding them.

The buzz the project created also made journalists report about EPS in magazines, on the radio and the BBC and certainly contributed to food growing gaining momentum in Leeds. The symbolic power of EPS is unquestionable. The initiative however, and despite the fact of being aware and fearing this risk, did not manage to involve new people living in the surroundings of the garden. Local residents remained a minority in the composition of the group, and despite consistent manifestation of interest and curiosity from part of new individuals, passers-by and locals, the group never really grew substantially and new members didn't take ownership of the project -or engaged with a proactive role - and once the key players moved on to other projects the group vanished. Some of the reasons for this are now clearer: the nature of grassroots, spontaneous and small size initiatives make them more exposed to the contingencies in their participants' lives. Changing in family commitments, workloads, and health conditions have a great impact on projects that rely on the commitment of a handful of people. Some of the events that actually impacted on the specific spatio-temporality of EPS were unpredictable. Other limiting factors are perhaps due to the specific course of action that has been deliberated by the group. While we can only speculate on this, we have surely to question whether the decision of going for a "legal way" in reclaiming the land has somehow impacted on the strategies adopted for gaining local support and engagement. For example, the seek for council support make un-necessary the use of more radical confrontational forms of struggle that could have helped identification with the other thousand of residents expropriated of their right to the city. This, as well as the socially constructed expectation of not having access to place design, or our embodied identities (white, highly educated 'better off'), might have contributed, as Kobayashi would put it, to be "constructed as others" (Kobayashi 1994, p. 75). 


\subsection{Food growing as element of urban planning}

As much as EPS has not been successful in involving new people, it has been successful in creating a community of food growers that managed to bring food growing as a local strategy on urban planning agendas. The experiment, in fact, turned out to be fertile in developing much needed tools to bridge the divide between grassroots groups and policy makers in urban planning. The power of agenda setting in urban planning has been recognized in the literature on public participation and social movements (Van Dyck 2011). Rather than affecting policy outcomes directly, the Leeds case shows its importance in steering policy attention to food growing as planning strategy through the appropriation and animation of an indeterminate sideway of a public footpath. The "in betweeness" position of the space was crucial in creating a temporary 'marge of manoeuver' and the improvised mode of action to take root (Tonnelat 2008). EPS also showed that community groups, with little resources, can question land use, negotiate land access and as such transcend boundaries of plan-build-use logics.

The confidence and solid group grown out of the EPS experience, contribute to formation of a new umbrella organisation, called Feed Leeds ([LINK UNDISCLOSED]), linking food growing projects across the all city and lobbying the Council for the development of a sustainable food strategy. The council since then has agreed to allocate 37 council parks for experimental food growing projects, where community groups will take responsibility for setting up and managing a community garden, and discussions are being developed around new food growing projects in council housing estates and in new areas under regeneration as experimental eco-settlements.

EPS furthermore made other systemic contradictions more visible. What with the fact that despite a heavy regulated system to simply gain permission to use space for a convivial event, we never received a written agreement to create raised beds, neither was it monitored. Was it just in the name of trust in the people involved in the project, who had working relationships with the council? Or actually a sign that heavy regulation in reality goes hand in hand with a porous system of land control?

\subsection{Organic praxis in urban food growing}

Engagement as a researcher in an activist group, meant to bring in specific analytical skills, but also the mere fact of being a reliable community member, who provides energy, commitment and reliability throughout the project.

The walking part of the "talk-plus-walk" approach (Pulido 2008) for a researcher belonging to the Leeds political gardening community also meant to enter in the sphere of bargaining in the political arena. Bringing in ideas about the expropriation from and the need of access of public space and food growing practices, defending these ideas and negotiating them with community members and council officials. In the initial stage of EPS, addressing the question of what could spatial quality signify when reflecting on it from a political gardening perspectives lead to the collective identification of qualities important for public space. During a workshop the collective identified edibility, sustainability, learning, joy and social interaction as characteristics of spatial quality. These became guiding principles in the creation of the garden in Buslingthorpe Walk. From then on the coming into being of the garden as well as its contribution as a learning platform became a shared responsibility. 
The freedom of improvisation, awareness of the immediate snowball effect - with local groups asking how to do the same in public patches of land nearby their homes - and the joy of conviviality among a very diverse range of people, all contributed to team building, through getting to know each other in our limits and gifts, build trust and ultimately allowing for individual creativity to emerge. As has been analysed in details on the basis of critical work with collectives (e.g. see Starhawk 2012, Vercauteren 2011), group building, understanding group dynamics, responding and mediating to individual needs in the group, setting up and changing the pace of the project, finding different ways of engaging members, on the basis of their skills, while balancing the need for novelty and the need for a space of confidence is crucial. The embeddedness of the researcher in a plethora of activities and projects that preceded EPS, helped "knowing the other" (Routledge 2004), and playing out the role of facilitator and activator of group dynamics that constituted the capacity to make an impact.

The multiplication of claims, showcasing of EPS across venues, conversations with councillors and the two pages policy brief that was circulated (that included ideas on how food growing in public space can help to promote educational and re-skilling activities and how local authorities can support community projects), all added up to stir in the council's member of the executive for Environmental policies, the decision to look into community food growing and alternative ways to manage public land. It was a time when England planning policy was changing under the influence of the Localism Act promulgated by the (conservative-libdem) coalition government, together with the prospective of progressive but substantial financial and jobs cuts. These meant that fewer resources would have been available to manage public land, while the legislative framework was making possible to transfer public assets under the responsibility of 'the Big Society'. While the apparently original Council's intent of setting up a network of food growers for exploring assets transfer has progressively disappeared alongside the changing roles in the executive and a Feed Leeds' identity in-the-making as "lobbying group", rather than as "Council's partner", this option remains dormant while different planning arenas slowly take shape. Questions remain open on how the Leeds political gardening initiatives will eventually go beyond serving the Councils interest of outsourcing responsibilities to the community in times of cuts, and so ultimately further privatising urban space.

\subsection{Storytelling and framing the narrative: too close to see?}

Finally, the embeddedness of activism into a research project, and the belonging of researchers to the gardeners' movement, generates tensions and questions about distance. Our direct involvement in both practices of insurgent urbanism and in food sovereignty initiatives gives us a deep understanding of the issues at stake and an embodied understanding of hidden conflicts. Commitment in the movement is based on a normative view on social and ecological justice. Consequently, the aim of this paper is to contribute to the creation of an active memory of political gardening. Such an approach starts from putting positioning and perspectives at stakes, rather than to compare alternatives. In adopting an approach that seeks to write stories from below, and learn by keeping track and retracing decisions that have been made throughout experiments we left behind notions of objectivity and rather took the research context and political goals of knowledge production as a starting point. 
The articulation of the action research project and a critical action has generated productive dynamics with regard to the tension of being too close to see/being to far to see. Joint analysis and writing of two authors that have been respectively closely and distantly involved in EPS allowed for an interesting exchange on what elements to identify and giving importance when trying to grasp what made EPS into an 'event' that changed the Leeds food growing scene. An event with a 'before' and an 'after'. Too close to see in that respect also refers to time. Making a comprehensible analysis of 'a movement' in the making is quasi impossible, as its agenda and strategy evolves continuously. Being both writing from within the case (in time and location) and watching it remotely mixed up the roles of acting, telling the story and framing it. This poses questions on our ability to distinguish what EPS intended to, and what it stands for today.

\section{Concluding notes}

Aware of the growing and largely advocating literature on urban agriculture, the paper aimed to unpack the contradictions and tensions between critical analysis and activistresearch, in a case of political gardening.

We started this trajectory posing ourselves a question: is the tension between our role as activists that experiment with transformative practices and their risks of co-optation, and our role of researchers, vigilant but also engaged with the challenge of providing tools for alternatives practices (Brenner 2009, Marcuse 2009) a contradiction? Where do we draw the line between urban agriculture advocacy, intended here as an undisputed commitment to reclaim the 'goods' of place re-appropriations for food growing purposes, and food sovereignty activism, less concerned with place and more alerted on the relational and political sensitivities of producing change? And should we? A number of discussions in the academic community are relevant for this reflection, for example debates around beautification and gentrification, uncritical advocacy and critical pessimism, and more in general around the capacity of neoliberal capitalism to colonise new spheres of life, of which the 'ecological turn' seems to be a manifestation (eg. Hodson and Marvin 2009, Whitehead 2013).

A way to answer this question has been the unfolding of the analytical trajectory based on a thick description that we have presented in this paper, analysing the project's role as activator of empowerment dynamics, public agenda settings and long term social change. Our "living activism" and on-going engagement has generated research material beyond the life of the project, and has therefore allowed for an experience-based writing able to link innovation and shortcomings of the projects, with its longer terms empowering effects. The form of presenting EPS as part of a history that builds upon other experiences, and that is the beginning of other stories represents our way to deal with the constant tension of our hybrid identities (as activist-scholars, or militant-researchers), our practices (as advocates, as activists, as action-researchers) and the risks of co-optation that punctuate the future. We know we can only take this tension with us in the trip on the struggle for social and ecological justice. A struggle which belongs to the never-ending journey of social change.

We see a form of deeply committed scholarly activism ("organic praxis") in political gardening as one option among many that will help to enrich the spectrum of resources needed to confront the challenges that urban food systems encompass. We sketched one path of how the combination of research and political engagement have been mutually enriching. 
We offered insights how this relation changed over time and showed how a political gardening initiative was a blend of political commitment, research practice and political context.

We presented a hopeful perspective on the possibilities of critical action. Writing about EPS as the heir of an emerging political gardening movement could rightly be criticized for being overly positive in its approach. A critique that we voluntarily accept. The idea of writing from below was also, and going back to Vercauteren (2011), part of a collective effort of providing the air needed for other experiments to breath. Being committed in social movements, we believe that telling engaging and inspiring experiences to which one can relate is a much-needed practice in reaction to the hegemonic of favoring the plausible over the possible.

\section{References}

Andres, L., 2012. Differential Spaces, Power Hierarchy and Collaborative Planning: A Critique of the Role of Temporary Uses in Shaping and Making Places. Urban Studies, 50 (4), 759-775.

Armstrong, D., 2000. A survey of community gardens in upstate New York; Implications for health promotion and community development. Health \& Place, 6, 319-327.

Bartling, H., 2012. A chicken ain't nothin' but a bird: local food production and the politics of land-use change. Local Environment, 17 (1), 23-34.

Bohn K. and Viljoen A. 2005. More city with less space: vision for lifestyle. In Viljoen A. editor, Continuous Productive Urban Landscapes: Designing Urban Agriculture for Sustainable Cities. Burlington MA and Oxford: Architectural Press.

Brenner, N., 2009. What is critical urban theory? City: analysis of urban trends, culture, theory, policy, action, 13 (2-3), 198-207.

Cahill, C. , 2007. Repositioning Ethical Commitments: Participatory Action Research as a Relational Praxis of Social Change. ACME: An International E-Journal for Critical Geographies, 6 (3), 360-373.

Castree, N., 2002. Border Geography. Area, 34, 103-108.

Colomb, C., 2012. Pushing The Urban Frontier: Temporary Uses Of Space, City Marketing, and The Creative City Discourse In 2000s Berlin. Journal of Urban Affairs, 34 (2), 131-152.

Dooling, S. 2009. Ecological gentrification: a research agenda exploring justice in the city. International Journal of Urban and Regional Research 33, 621-639.

Doucet, I. 2011. Learning from Brussels. An irreductive approach to architectural and urban problématiques? Belgeo, 2011(1-2), 29-40.

Doucet, I., and Janssens, N., 2011. Transdisciplinary knowledge production in architecture and urbanism towards hybrid modes of inquiry. Dordrecht: Springer. http://public.eblib.com/EBLPublic/PublicView.do?ptiID=666719.

Firth, C., Maye, D. and Pearson, D., 2011. Developing "community" in community gardens. Local Environment, The International Journal of Justice and Sustainability, 16 (6), $555-568$.

Garnett, T., 1996. Harvesting the cities. Town and Country Planning, 65 (9), 264-265.

Gibson-Graham, J.K. 2008. Diverse Economies: Performative Practices for "Other Worlds". Progress in Human Geography, 32(5), 613-32. 
Gibson-Graham, J.K., 2006. A post capitalist politics. Minneapolis: University of Minnesota Press.

Gilmore, R.W, 1993. Public enemies and private intellectuals: Apartheid USA. Race Class $35(1), 69$.

Glover, T.D., Shinew, K.J. and Parry, D.C., 2005. Association, Sociability, and Civil Culture: The Democratic Effect of Community Gardening. Leisure Sciences, 27(1), 75-92.

Harris, E., 2009. Neoliberal subjectivities or a politics of the possible? Reading for difference in alternative food networks. Area, 41(1), 55-63.

Heynen, N., 2010. Cooking up non-violent civil-disobedient direct action for the hungry: 'Food Not Bombs' and the resurgence of radical democracy in the US. Urban Studies, 47 (6), 1225-1240.

Hodgkinson, T., 2005. Digging for anarchy. In T. Richardson and N. Kingsbury, eds. 2005. Vista. The culture and politics of gardens. London: Frances Lincoln.

Hodkinson, S., 2012. The New Urban Enclosures. City: analysis of urban trends, culture, theory, policy, action, 16 (5), 500-518.

Holland, L., 2004. Diversity and connections in community gardens: a contribution to local sustainability. Local Environment, The International Journal of Justice and Sustainability, 9(3), 285-305.

Hou J., Johnson J.M. and Lawson L. J. 2009. Greening cities, growing communities. Learning from Seattle's urban community gardens. Seattle \& London: University of Washington Press.

Hou, J., editor, 2010. Insurgent public space. Guerrilla Urbanism and the remaking of contemporary cities. London: Routledge.

Howe J. and Wheeler, P., 1999. Urban food growing: The experience of two UK cities. Sustainable development, 7(1), 13-24.

Irvine S., Johnson 1. \& K. Peters, 1999. Community gardens and sustainable land use planning: A case-study of the Alex Wilson community garden. Local Environment: The International Journal of Justice and Sustainability, 4 (1), 33-46.

Jackson, T., 2009. Prosperity without growth. Economics for a finite planet. London: Earthscan.

Jamar, D. , 2012. Art-Activisme: enjeux de créativité urbaine à Bruxelles, L'Information géographique 76(3), $24-35$.

Kobayashi, A., 1994. Colouring the field: 'Race' and the politics of fieldwork. Professional geographer, 46 (1), 73-80.

Latour, B. 2004. Why has critique run out of steam? From matters of facto to matters of concern. Critical Inquiry, 30(2):, 225-248.

Le Strat, P. N., 2004. Un projet d'Éco-urbanité. L'expérience d'ECObox dans le quartier La Chapelle à Paris. Constitution et agencement du projet. Notes et Études $n^{\circ} 4$ Juillet 2004 ISCRA (Institut Social et Coopératif de Recherche Appliquée) www.iscra.org

Lefebvre, H., 1991[1974].. The production of space. Oxford: Blackwell.

Lévesque, L., 2002. "The 'Terrain Vague' as Material-Some Observations." House Boat/Occupations Symbiotiques, Hull/Gatineua: AXENEO7, pp6-7.

Madanipour, A., 2013. Researching Space, Transgressing Epistemic Boundaries. International Planning Studies, 18 (3-4), 372-388.

Marcuse, P., 2009. From critical urban theory to the right to the city. City: analysis of urban trends, culture, theory, policy, action, 13 (2-3), 185-197. 
Mariani, M. and Barron, P., 2014. Terrain vague: interstices at the edge of the pale. New York: Routledge.

Marsden T. and Franklin A. 2013. Replacing neoliberalism: theoretical implications of the rise of local food movements. Local Environment, The International Journal of Justice and Sustainability, 18 (5), 636-641.

Hodson M., and Marvin, S., 2009. 'Urban Ecological Security': A New Urban Paradigm? International Journal of Urban and Regional Research, 33 (1), 193-215.

McClintock, N., 2013. Radical, reformist, and garden-variety neoliberal: coming to terms with urban agriculture's contradictions. Local Environment: The International Journal of Justice and Sustainability , DOI: 10.1080/13549839.2012.752797, 1-25.

Milligan, C., Gatrell, A. and Bingley, A., 2004. Cultivating health: therapeutic landscapes and older people in northern England. Social Science and Medicine, 58(9), 1781-1793.

Minton, A. , 2012. Ground control. Fear and Happiness in the Twenty-First Century City. London: Penguin Books.

Miraftab, F., 2009. Insurgent Planning: Situating Radical Planning in the Global South. Planning Theory, 8(1), 32-50.

Moulaert, F. , MacCallum, D., Mehmood, A., Hamdouch, A. 2013. The International Handbook On Social Innovation. Collective Action, Social Learning and Transdisciplinary Research. Cheltenham : Edward Elgar.

Nicolette L., Lyons K. and Woolcock G., 2013. Enacting food sovereignty: values and meanings in the act of domestic food production in urban Australia, in Local Environment, The International Journal of Justice and Sustainability, DOI: 10.1080/13549839.2012.716409

Pain, R. 2003. Social geography: on action orientated research. Progress in Human Geography, 27 (5), 649-657.

Petcou, C. and Petrescu, D., 2007. Acting Space. Transversal notes, on-the-ground observations and concrete questions for us all. In: aaa-PEPRAV Eds, 2007. Urban Act. Paris: aaa-PEPRAV, pp. 319-328.

Pinkerton, T. and Hopkins, R., 2009. Local food. How to make it happen in your community. Totnes: Transition Books.

Piven, F.F., 2010. Reflections on scholarship and activism. Antipode, 42(4): 806-810.

Public Space Public Produce group (PSPP), 2012. Policy recommendations for Leeds City Council.

Pudup, M. B., 2008. It takes a garden: Cultivating citizen-subjects in organized garden projects. Geoforum, 39 (3), 1228-1240.

Pulido, L., 2008. FAQs: Frequently Asked Questions on Being a Scholar/Activist. C. R. Hale (ed.), Engaging Contradictions: Theory, Politics and Methods of Activist Scholarship. Berkeley: University of California Press. Pp. 341-366.

Robbins P. and Sharp, J., 2004. The Lawn-Chemical Economy and Its Discontents. Antipode, 35 (5), 955-978.

Routledge, P., 2004. Relational ethics of struggle. D. Fuller and R. Kitchin R. eds., Radical Theory/Critical praxis: Making a Difference Beyond the Academy?, Kelowna: Praxis (e)Press, Ch. 7, pp. 79-91

Saed 2012. Urban Farming: The Right to What Sort of City? Capitalism Nature Socialism 23, $1-9$.

Shillington, L. 2013. Right to food, right to the city: Household urban agriculture, and socionatural metabolism in Managua, Nicaragua. Geoforum, 44 (1), 103-111. 
Starhawk 2012. The empowerment manual. A guide for collaborative groups. Gabriola Island : New Society Publishers.

Steel, C., 2008. Hungry City. How food shapes our lives, London: Vintage.

Stengers, I., 2005. The Cosmopolitical Proposal. B. Latour and P. Weibel, eds., Making Things Public - Atmospheres of Democracy, Cambridge/Massachusets/London: ZKM and The MIT Press, pp. 994-1003.

Tonnelat, S., 2008. Out of frame: The (in)visible life of urban interstices: a case study in Charenton-le-Pont, Paris, France. Ethnography, 9, 291-324.

Tornaghi, C., 2014. Critical geography of urban agriculture. Progress in Human Geography, p.1-17, DOI: 10.1177/0309132513512542.

Van Dyck, B., 2011. Multiple voices, competing spatial claims: Social innovation and the transformation of the Angus Locoshops brownfield site (Montréal). In: Oosterlynck S., Van den Broeck J., Albrechts L., Moulaert F., Verhetsel A. (Eds.), Strategic Spatial Projects. Catalysts for Change. London: Routledge. Chapt. 3 (pp. 27-52).

Vercauteren, D., 2011 [2003]. Micropolitiques des groupes. pour une écologie des pratiques collectives. Paris: Les prairies ordinaires.

van den Berg et al., 2010. Allotment gardening and health: a comparative survey among allotment gardeners and their neighbors without an allotment. Environmental Health, $9(1), 74-85$.

Wakefield S., Yeudall F., Taron C., Reynolds J. and Skinner A., 2007. Growing urban health: community gardening in South-East Toronto. Health promotion international, $22,92-101$.

Whitehead, M., 2013. Neoliberal urban environmentalism and the adaptive city. Urban Studies, 50, 1348-67.

[1] SPINDUS (Spatial Innovation, Planning, Design and User Involvement) is a transdisciplinary research project, on the reading, assessment and making of spatial quality in space and place, funded by the Flemish Science and Technology Agency (IWT) 2009-2013.

${ }^{[2]}$ An ESRC funded grant for the project titled "[TITLE UNDISCLOSED] " (Grant number: [NUMBER UNDISCLOSED]) that established the [UNDISCPLOSED] social platform on urban agriculture (see [LINK UNDISCLOSED]) 